\title{
INHIBITION OF LIPID ACCUMULATION IN 3T3-L1 ADIPOCYTES BY MORINDA CITRIFOLIA LINN. LEAF EXTRACTS AND COMMERCIAL HERBAL FORMULAS FOR WEIGHT CONTROL
}

\author{
AURASORN SARAPHANCHOTIWITTHAYA ${ }^{1,2^{*}}$, PATTANA SRIPALAKIT ${ }^{2,3}$ \\ ${ }^{1}$ Department of Pharmaceutical Technology, ${ }^{2}$ Pharmaceutical Biotechnology Research Unit, ${ }^{3}$ Department of Pharmaceutical Chemistry \\ and Pharmacognosy, Faculty of Pharmaceutical Sciences, Naresuan University, Phitsanulok 65000 Thailand \\ Email: aurasorns@nu.ac.th
}

Received: 01 Sep 2016 Revised and Accepted: 15 0ct 2016

\begin{abstract}
Objective: To determine the in vitro anti-obesity effects of Morinda citrifolia leaf extract and herbal formulas used for weight loss in Thailand on lipid accumulation in 3T3-L1 adipocytes.

Methods: Differentiated 3T3-L1 adipocytes were treated with 0.1, 0.5 and $1 \mathrm{mg} / \mathrm{ml}$ M. citrifolia leaf extract, three herbal formulas (JL-RU, JL-TH, CD$\mathrm{H}$ ) and 1, 5 and $10 \mu \mathrm{g} / \mathrm{ml}$ rutin, gallic acid and caffeine. Lipid accumulation determined by measuring Oil Red 0 staining and triglyceride content measured by a colorimetric method in adipocytes were assayed compared to the control. The effect of test samples on the viability of preadipocytes and differentiated adipocytes were investigated.

Results: Differentiated adipocytes treated with $1 \mathrm{mg} / \mathrm{ml}$ M. citrifolia extract moderately inhibited fat accumulation (45.12\%) and highly reduced triglyceride content (85.09\%). Among the three herbal formulas, JL-TH considerably inhibited fat accumulation (109.17\%, $1 \mathrm{mg} / \mathrm{ml}$ ) and decreased triglyceride content $(95.00 \%, 1 \mathrm{mg} / \mathrm{ml})$ in adipocytes; this was higher than that for CD-H and JL-RU, respectively. The viability of preadipocytes treated with CD-H at $1 \mathrm{mg} / \mathrm{ml}$ was slightly decreased while those treated with JL-TH at $0.05-1 \mathrm{mg} / \mathrm{ml}$ showed moderately decreased viability in a dose-response manner. For differentiated adipocytes, CD-H at 0.5-1 mg/ml moderately decreased cell viability while JL-TH at 0.05-1 mg/ml caused moderate to high reduction of cell viability in a dose-response relationship.
\end{abstract}

Conclusion: $M$. citrifolia extract and three herbal formulas had anti-obesity effects in 3T3-L1 adipocytes, as indicated by a significant reduction in lipid accumulation, triglyceride content, and cell viability. These findings suggest a potential therapeutic approach for the prevention and treatment of obesity.

Keywords: 3T3-L1 adipocytes, Adipogenesis, Anti-obesity, Triglyceride, Morinda citrifolia, Herb for weight loss

(C) 2016 The Authors. Published by Innovare Academic Sciences Pvt Ltd. This is an open access article under the CC BY license (http://creativecommons.org/licenses/by/4. 0/) DOI: http://dx.doi.org/10.22159/ijpps.2016v8i12.15005

\section{INTRODUCTION}

In the present climate, obesity has become a major global health problem and cause of death in humans worldwide. It is a chronic metabolic disorder caused by an unhealthy lifestyle, eating behaviors and an imbalance between energy intake and expenditure. However, diet and physical exercise are usually not very effective, and most patients regain weight even after successful weight loss [1]. Obesity is a major social health problem in many developed countries, and a risk factor associated with the development of type II diabetes, coronary heart disease, hyperlipidemia, hypertension and metabolic syndromes [2, 3], certain types of cancer and osteoarthritis [4]. In recent years, several anti-obesity drugs have been approved and marketed to treat obesity. However, most of them have been withdrawn due to their risk of severe side effects such as heart valve damage, cardiovascular disease and psychiatric disorders [5]. Currently, orlistat, which acts as a lipase inhibitor, preventing the absorption of fats from the human diet, has been used for the treatment of obesity due to its safety. However, it is not as effective as other drugs in reducing body weight, and it also has unpleasant and non-negligible side effects [6].

The discovery of bioactive compounds from food, food supplements and various parts of plants has provided alternative ways to manage obesity and reduce the risks of obesity related-diseases. Examples of herbs used in the treatment of obesity are Commiphora mukul, Pterocarpus marsupium, Fucus vesiculosis, Gymnema sylvestre, Salacia reticulate, etc. [7]. Some natural products such as Nepeta japonica Maximiwicz extract were found to inhibit triglyceride accumulation in 3T3-L1 adipocytes and trigger lipolysis via the released glycerol [4]. In vivo study, repeated oral administration of tubers of Cyperus rotundus L. aqueous extract can evoke a potent anti-obesity activity in rats fed on high-fat cafeteria diet [8].
Nowadays, expansion of the pharmaceutical and dietary supplement market is continuously increasing and the market remains strongly competitive especially nutraceuticals. Presently, numerous dietary supplements for weight control have been launched on the market. Their mechanisms of action are different, such as blocking starch, preventing fat absorption, inducing lipolysis or increasing metabolism. Dietary supplements or nutraceuticals, as claimed, are composed of vitamins, some amino acids, single plants or plant formulations, or a mixture. It is already known that some herbs and dietary supplements are effective, but not for all users. A market survey revealed the availability of Ayurvedic/herbal anti-obesity products in pharmacy and online shopping website. Most of the herbal medicines for anti-obesity have Triphala followed by garcinia and guggul as part of the composition or used individually. As per pharmacist, $60-70 \%$ of anti-obesity herbs are being purchased without a prescription. There are many online websites available, selling anti-obesity herbs with titles of safety and guaranteed weight loss [9]. However, an important obstacle which has hindered the acceptance of using herbs and dietary supplement is the lack of scientific confirmation and quality control.

M. citrifolia or "noni" (family Rubiaceae), has been used in folk remedies for over $2000 \mathrm{y}$. Pharmacological activities of $M$. citrifolia such as antioxidant activity, antibacterial activity, liver protective activity, antifungal activity, anxiolytic activity, estrogenic activity, immunological activity, analgesic activity and cancer preventive effect have been reported [10]. However, their anti-obesity-related activity has rarely been studied. A previous investigation revealed that $M$. citrifolia leaves had an anti-inhibitory effect on lipoprotein lipase (LPL). Various extraction techniques to prepare $M$. citrifolia extracts affected their anti-lipase activities. The extract prepared by freezedrying the juice of fresh leaves could be an effective anti-obesity 
candidate to manage body weight [11]. We hypothesized that this extract would have other anti-obesity-related activities, so it was investigated in this study, compared with rutin, its major component. JL-RU, JL-TH (Jatupalathika formula) and CD-H were herbal formulas used for weight control and fat loss, which are sold in Thailand. We used these herbal formulas in the study since there were some unofficial reports of their successful use for weight control but there were no scientific reports regarding anti-obesity potentials. Gallic acid, which was a major active component in Jatupalathika and is generally contained in various herbs, was investigated.

The aim of this study was to determine the in vitro anti-obesity effects of M. citrifolia leaf extract and some herbal formulas which claimed weight control or fat loss in Thailand. The scientific confirmation of their anti-obesity effects might provide evidence for the prevention and treatment of obesity.

\section{MATERIALS AND METHOD}

\section{Chemicals and reagents}

Foetal bovine serum (FBS) was purchased from GIBCO (Invitrogen, NY, USA). Penicillin-streptomycin solution, Dulbecco's modified Eagle medium (DMEM containing high glucose, L-glutamine, sodium pyruvate), insulin (INS), dexamethasone (DEX), 3-isobutyl-1-methyl xanthine (IBMX), MTT [3-(4,5-dimethylthiazol-2-yl)-2,5-diphenyltetrazolium bromide], caffeine, rutin, gallic acid, Oil Red 0 solution, phosphate buffered saline (PBS), dimethyl sulfoxide (DMSO) and triglyceride (TG) assay kits were obtained from Sigma (MO, USA). All solvents and reagents were of analytical grade.

\section{Cell culture}

3T3-L1 cells, obtained from the American Type Culture Collection (ATCC, Rockville, MD, USA), were grown in culture plates containing DMEM supplemented with $10 \%$ heat-inactivated FBS, 100 units/ml penicillin and $100 \mu \mathrm{g} / \mathrm{ml}$ streptomycin. The cultures were kept at $37{ }^{\circ} \mathrm{C}$ in a humidified chamber with $5 \% \mathrm{CO}_{2}$. The medium was changed every $2 \mathrm{~d}$.

\section{Differentiation of 3T3-L1 cells to adipocytes}

The 3T3-L1 preadipocytes were plated in 24-well plates at a density of $3 \times 10^{4}$ cells/well and cultured in DMEM containing $25 \mathrm{mmol} / \mathrm{l}$ glucose, $1 \mathrm{mmol} / \mathrm{l}$ sodium pyruvate, $4 \mathrm{mmol} / \mathrm{l}$ L-glutamine, $10 \%$ heat-inactivated FBS, $100 \mathrm{U} / \mathrm{ml}$ penicillin and $100 \mu \mathrm{g} / \mathrm{ml}$ streptomycin at $37{ }^{\circ} \mathrm{C}$ in $5 \% \mathrm{CO}_{2}$. To induce differentiation, $2 \mathrm{~d}$ after confluence (day 0), the medium was removed and fresh differentiation medium containing $0.5 \mathrm{mmol} / \mathrm{l}$ IBMX, $2.5 \mu \mathrm{mol} / \mathrm{l}$ DEX, $10 \mu \mathrm{g} / \mathrm{ml}$ insulin INS was added. Test samples were added to the culture medium every $2 \mathrm{~d}$. By day 12 , more than $90 \%$ of the cells had differentiated into rounded cells with lipid droplets. Cells and culture medium were collected for further assays.

\section{Plant materials and herbal formulas}

Morinda citrifolia Linn. was collected from Ban-thi District, Lamphun Province, Thailand in January 2015. The plant was authenticated by a botanist from the Office of the Forest Herbarium, Department of National Parks, Wildlife and Plant Conservation, Bangkok, Thailand. A voucher specimen (183646) was also prepared and deposited at the Office of the Forest Herbarium, Department of National Parks, Wildlife and Plant Conservation, Bangkok, Thailand.

JL-RU, JL-TH and CD-H were herbal formulations used for weight control or fat loss in Thailand. Ingredients of the herbal formulations were labelled as dried powder of various plants, as shown in table 1. Caffeine was used as a positive control, and rutin, which was a major component of M. citrifolia, and gallic acid, a major component of herbal mixture in JL-TH and various herbs, were studied.

\section{Preparation of herbal test samples}

M. citrifolia (MC) leaves were cleaned with tap water, rinsed with distilled water and chopped into small pieces. MC extract was obtained by the homogenisation of fresh leaves $(350 \mathrm{~g})$ with distilled water $(800 \mathrm{ml})$. The leaf juice was filtered and concentrated by freeze-drying [9]. MC extract and three herbal formulas (JL-RU, JL-TH and $\mathrm{CD}-\mathrm{H})(100 \mathrm{mg})$ were weighed and dissolved in distilled water $(10$ $\mathrm{ml}$ ) to prepare $10 \mathrm{mg} / \mathrm{ml}$ stock solution. The mixtures were sonicated for $15 \mathrm{~min}$, then centrifuged at $5000 \mathrm{rpm}$ for $10 \mathrm{~min}$. The supernatants were collected and filtered. Stock solutions $(1 \mathrm{mg} / \mathrm{ml})$ of rutin, gallic acid and caffeine were prepared by dissolving in distilled water. The test solution of MC extract and herbal formulas at $0.1,0.5$ and $1 \mathrm{mg} / \mathrm{ml}$ and rutin, gallic acid and caffeine at final concentrations of 1,5 and $10 \mu \mathrm{g} / \mathrm{ml}$ were prepared for further assays.

Table 1: List of herb ingredients in herbal formulas

\begin{tabular}{lll}
\hline Herbal formulas (code) & Ingredients & \\
\hline JL-RU & Albizia procera & Boesenbergia rotunda \\
& Diospyros rhodocalyx & Piper nigrum \\
& Tinospora crispa & \\
& Streblus asper & Terminalia arjuna \\
JL-TH & Terminalia chebula & Phyllanthus emblica \\
& Terminalia bellerica & Garcinia atroviridis \\
CD-H & Piper nigrum & \\
& Senna alexandrina & \\
\hline
\end{tabular}

\section{Cell viability assay}

The MTT assay was performed according to the method of Mosmann [12]. The viability of post-confluent preadipocytes was assayed. Cells were seeded in each well of a 24 -well plate $\left(3 \times 10^{4}\right.$ cells/well $)$ and grown at $37{ }^{\circ} \mathrm{C}$ in a humidified chamber with $5 \% \mathrm{CO}_{2}$ for $24 \mathrm{~h}$. Test solutions $(100 \mu \mathrm{l})$ were added to the cultures; cell viability was assayed after $24 \mathrm{~h}$. For the viability of differentiated cells, postconfluent preadipocytes were treated with test solution $(100 \mu \mathrm{l})$ in differentiation medium every $2 \mathrm{~d}$ for $12 \mathrm{~d}$; after that, the viability was assayed. Then, $5 \mathrm{mg} / \mathrm{ml}$ MTT solution in PBS solution, $\mathrm{pH} 7.4$ $(10 \mu \mathrm{l})$ was added to each well. After $30 \mathrm{~min}$, the culture medium was discarded and DMSO: ethanol (1:1) solution $(200 \mu \mathrm{l})$ was added, before being mixed. The absorbance was measured at $595 \mathrm{~nm}$ using a microplate reader (Eon, BioTek Instruments, USA). \%Viability was calculated as follows:

$$
\% \text { viability }=\left(\frac{O D_{\text {sample }}}{O D_{\text {control }}}\right) \times 100
$$

\section{Lipid accumulation assay by oil red 0 staining}

The lipid content in the adipocytes was determined using the Oil Red 0 staining assay as previously described [4]. The differentiation medium was incubated with either test samples or a vehicle at day 0 and cultured for $12 \mathrm{~d}$. Media and treatments were changed every 2 d. On day 12, cells were washed with PBS solution and fixed in fresh $10 \%$ formaldehyde for $1 \mathrm{~h}$. After that, cells were washed with $60 \%$ isopropanol and stained with Oil Red 0 dye solution $(0.6 \%$ Oil Red 0 dye in isopropanol: water solution, 6:4) for 15 min then washed with distilled water 3 times. Fat droplets stained red were extracted from cells by adding isopropanol to each well and mixing. The absorbance was measured at $500 \mathrm{~nm}$ using a microplate reader to calculate fat accumulation.

\section{Lipid accumulation assay by triglyceride (TG) determination}

Total cellular concentrations of TG were determined by a coupled enzyme assay, which results in a colorimetric product, proportional to the TG content. Treated 3T3-L1 adipocytes at day 12 were 
washed gently with PBS solution twice. Lipid extraction buffer (100 $\mu \mathrm{l})$ was added to cells, and then plates were sealed and incubated for $30 \mathrm{~min}$ at $90{ }^{\circ} \mathrm{C}$. The plates were cooled to room temperature and shaken for $1 \mathrm{~min}$ to homogenise the solution. The cloudy solution was analysed to determine TG contents using a commercial TG assay kit according to the manufacturer's instructions (Sigma-Aldrich, USA). The absorbance was measured at $570 \mathrm{~nm}$ using a microplate reader to calculate TG content.

\section{Statistical analyses}

Statistical analyses were conducted by one-way ANOVA with the post-hoc test; $p<0.05$ was regarded as statistically significant.

\section{RESULTS AND DISCUSSION}

\section{Preparation of herbal test samples}

MC extract was prepared by freeze-drying aqueous juices of $M$. citrifolia fresh leaves. The percentage yield of MC extract was $6.77 \%$ $\mathrm{w} / \mathrm{w}$ of fresh leaves. The physical appearance of MC extract was a dried greenish powder. HPLC analysis revealed that rutin was a major phytocompound in the extract [11] and would be tested and compared with MC extract.

\section{Cell viability assay}

Effects of MC extract and three herbal formulas on the viability of 3T3-L1 preadipocytes and differentiated adipocytes were determined using the MTT assay, compared to the control. This assay is based on the mitochondrial reduction of MTT to formazan, which is directly proportional to the number of living cells in culture [12]. For preadipocytes, MC at $0.1-1 \mathrm{mg} / \mathrm{ml}$, JL-RU at $0.1-1 \mathrm{mg} / \mathrm{ml}$ (data not shown), high dose of JL-RU at $1-10 \mathrm{mg} / \mathrm{ml}, \mathrm{CD}-\mathrm{H}$ at $0.05-$ $0.5 \mathrm{mg} / \mathrm{ml}$, caffeine, rutin, gallic acid at $1-5 \mu \mathrm{g} / \mathrm{ml}$ did not cause an alteration of viable cell numbers. In contrast, CD-H at $1 \mathrm{mg} / \mathrm{ml}$ slightly decreased cell viability while JL-TH at $0.05-1 \mathrm{mg} / \mathrm{ml}$ moderately decreased cell viability in a dose-response relationship.

The viability of differentiated adipocytes was not affected by MC at $0.1-1 \mathrm{mg} / \mathrm{ml}$, JL-RU at $0.1-1 \mathrm{mg} / \mathrm{ml}, \mathrm{CD}-\mathrm{H}$ at $0.1 \mathrm{mg} / \mathrm{ml}$, or caffeine, rutin, gallic acid at $1-5 \mu \mathrm{g} / \mathrm{ml}$. On the other hand, a high dose of JL$\mathrm{RU}$ at $5 \mathrm{mg} / \mathrm{ml}$ and $\mathrm{CD}-\mathrm{H}$ at $0.5-1 \mathrm{mg} / \mathrm{ml}$ moderately decreased adipocyte viability while JL-TH at $0.05-1 \mathrm{mg} / \mathrm{ml}$ caused a moderate to a high reduction in cell viability in a dose-dependent manner. The percentage of viability of preadipocytes and differentiated adipocytes is shown in fig. 1 and 2, respectively.

The 3T3-L1 cell line, commonly used as a model of adipocyte differentiation and fat accumulation, was used in this study. Differentiation of preadipocytes into adipocytes is an essential step to obtain mature adipocytes, which possess the capability to take up, synthesize and store lipids [13]. Cell viability of 3T3-L1 preadipocytes and differentiated adipocytes treated with various concentrations of test samples was assayed. The results showed that M. citrifolia extract, JL-RU, rutin, gallic acid, and caffeine did not influence the proliferation and viability of both pre-adipocytes and adipocytes. Treatment with JL-TH and CD-H reduced the number of viable preadipocytes, contributing to a suppression of cell viability and proliferation. This may be a potential mechanism for reducing the number of adipocytes. Moreover, the viability of differentiated adipocytes treated with JL-TH and CD-H was declined. These were lower than in preadipocytes. It might be speculated that both JL-TH and $\mathrm{CD}-\mathrm{H}$ inhibited cell proliferation and induced apoptosis in preadipocytes and differentiated adipocytes. Moreover, both test samples might affect adipogenesis. However, a specific assay is needed to confirm whether the reduction in cell number was caused by apoptosis.
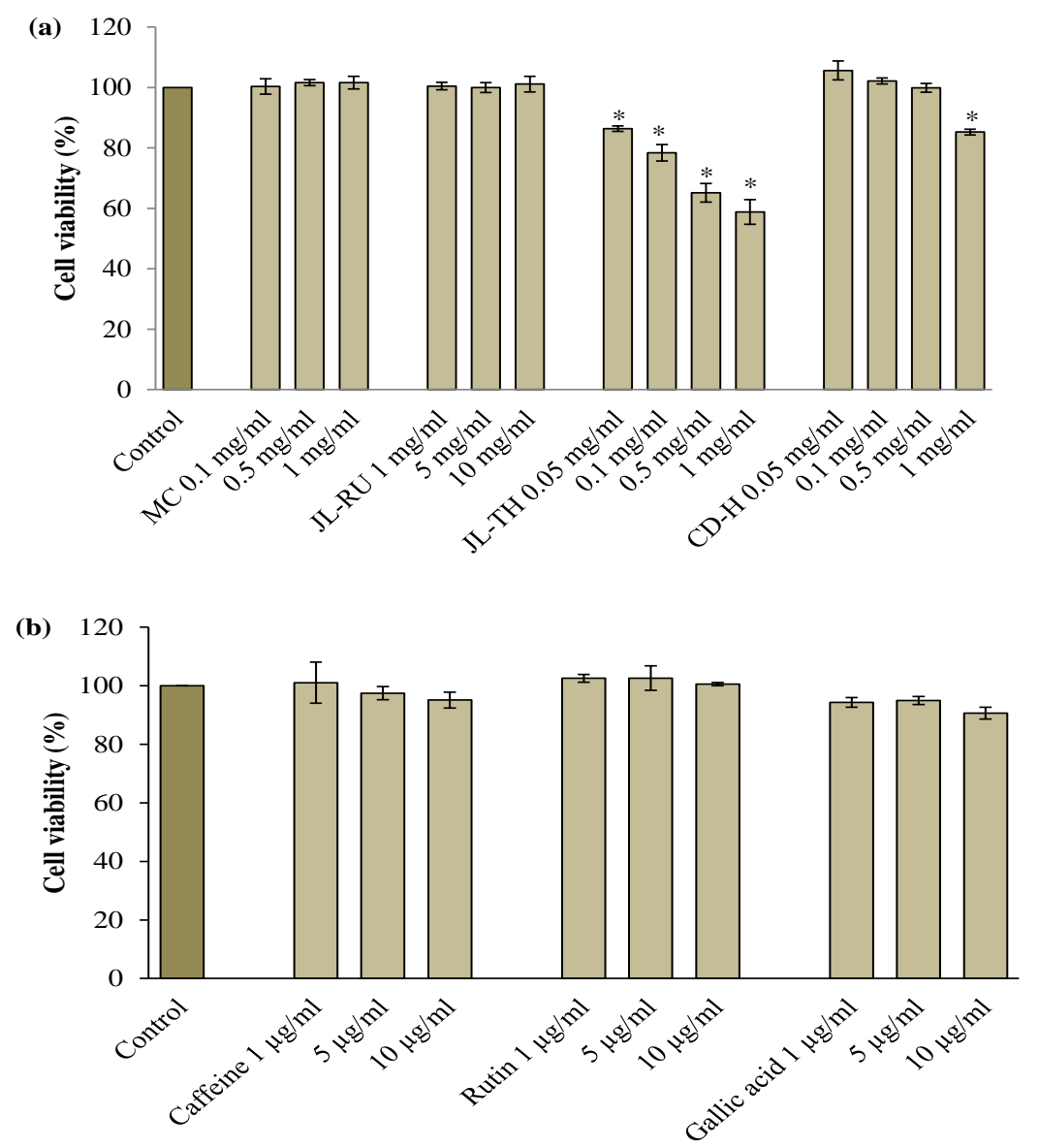

Fig. 1: Cell viability of 3T3-L1 preadipocytes treated with (a) MC (M. citrifolia), herbal formulas (JL-RU, JL-TH and CD-H), and (b) caffeine, rutin and gallic acid, compared to the control. Values are expressed as mean $\pm \mathrm{SE}(\mathrm{n}=3),{ }^{*} \boldsymbol{p}<0.05$ 


\section{Lipid accumulation assay}

The cell volume of adipocytes is mainly dependent on the accumulation of triacylglycerols. The differentiated adipocytes were stained with Oil Red 0 solution, and their lipid contents were quantified spectrophotometrically. Oil Red 0 staining was performed to examine the extent of lipid accumulation in 3T3-L1 adipocytes undergoing adipogenesis. The results showed that untreated differentiated adipocytes contained many lipid droplets, indicating lipid accumulation. The treatment of adipocytes with MC, JL-RU, JL-TH and CD-H at $0.1-1 \mathrm{mg} / \mathrm{ml}$ and caffeine, rutin and gallic acid at $1-5 \mu \mathrm{g} / \mathrm{ml}$ dose-dependently inhibited lipid accumulation. The maximum inhibition of lipid accumulation was observed in the treatment of JL-TH at $1 \mathrm{mg} / \mathrm{ml}(109.17 \%)$. The maximum inhibition of lipid accumulation by the treatment of MC, JL-RU, and CD-H was $45.12 \%(1 \mathrm{mg} / \mathrm{ml}), 56.51 \%(1 \mathrm{mg} / \mathrm{ml})$ and $67.52 \%(1 \mathrm{mg} / \mathrm{ml})$, respectively, while that of caffeine, rutin, gallic acid was $68.69 \%$, $57.80 \%$ and $62.03 \%$ at $10 \mu \mathrm{g} / \mathrm{ml}$, respectively. The effects of each test sample on intracellular lipid accumulation in 3T3-L1 adipocytes are shown in fig. 3 .
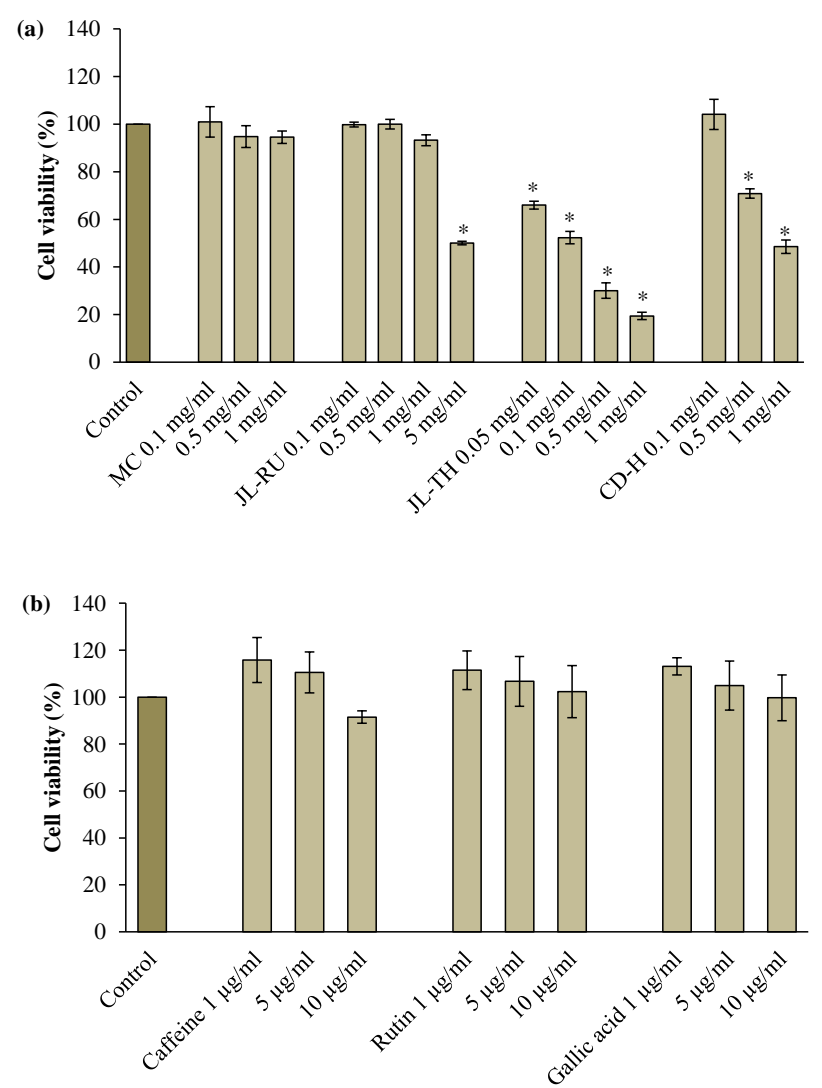

Fig. 2: Cell viability of 3T3-L1 adipocytes treated with (a) MC (M. citrifolia), herbal formulas (JL-RU, JL-TH, CD-H), and (b) caffeine, rutin and gallic acid, compared to the control. Values are expressed as mean \pm SE $(n=3),{ }^{*} p<0.05$

Intracellular TG content of 3T3-L1 cells was determined by colorimetric assay. The amount of TG in 3T3-L1 cells treated with MC, three herbal formulas, caffeine, rutin and gallic acid was decreased in a dose-dependent manner. The maximum inhibition of TG accumulation was observed in the presence of $1 \mathrm{mg} / \mathrm{ml} \mathrm{JL}-\mathrm{TH}$ (95\%) and CD-H (90.20\%). The maximum inhibition of TG deposition in adipocytes for MC, JL-RU, caffeine, rutin and gallic acid was approximately $85.09 \%(1 \mathrm{mg} / \mathrm{ml}), 68.76 \%(1 \mathrm{mg} / \mathrm{ml}), 33.52 \%$ $(10 \mu \mathrm{g} / \mathrm{ml}), 35.33 \%$ (10 $\mu \mathrm{g} / \mathrm{ml})$ and $48.33 \%$ to $33.52 \%(10 \mu \mathrm{g} / \mathrm{ml})$, respectively. The results are illustrated in fig. 4. \%Inhibition of lipid and TG accumulation in 3T3-L1 adipocytes treated with M. citrifolia, three herbal formulas (JL-RU, JL-TH and CD-H), caffeine, rutin and gallic acid is presented in table 2 .
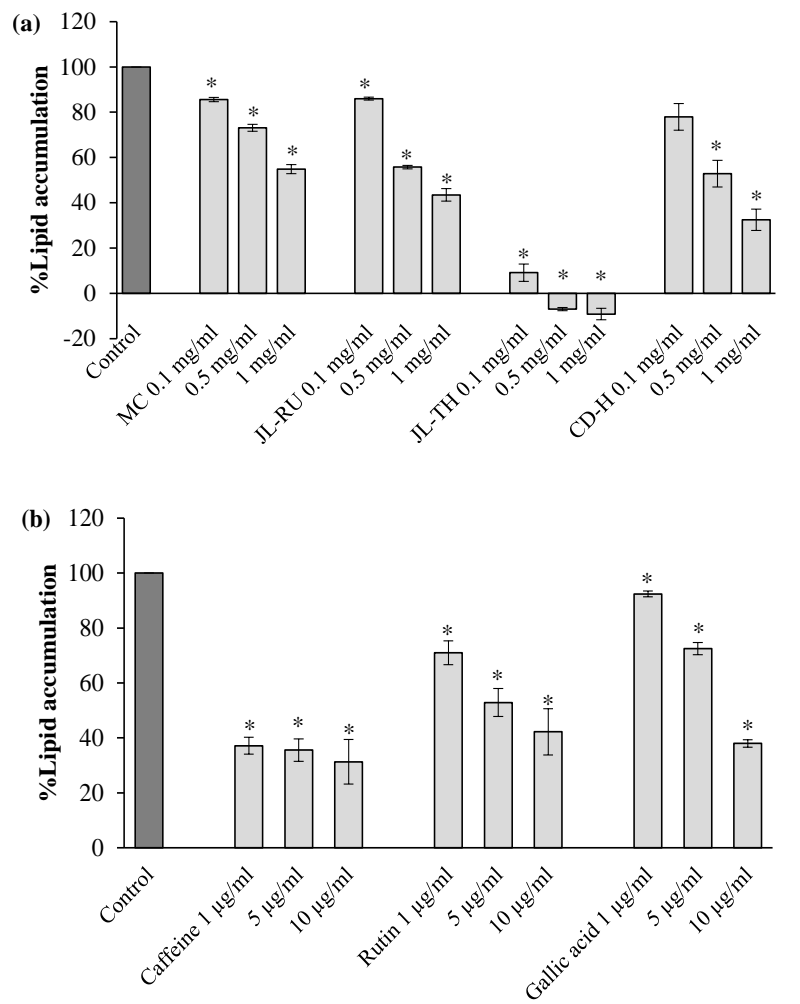

Fig. 3: Effects of (a) MC (M. citrifolia), herbal formulas (JL-RU, JLTH, CD-H), and (b) caffeine, rutin and gallic acid on lipid accumulation in 3T3-L1 adipocytes by Oil Red 0 technique, compared to the control. Values are expressed as mean $\pm \mathrm{SE}(n=$ 3), ${ }^{*} p<0.05$

Our finding stated that $\mathrm{MC}$ extract moderately inhibited fat accumulation and highly reduced triglyceride content in adipocytes. Rutin, a major component in $M$. citrifolia leaves, may be partially responsible for this activity due to the similar activity. Three herbal formulas (JL-RU, JL-TH and CD-H) exhibited the inhibition of fat accumulation and diminution of TG content in 3T3-L1 adipocytes with a dose-response relationship. Interestingly, JL-TH was the most potent formulation on the suppression of fat accumulation and TG deposition in adipocytes. It was more potent than CD-H and JL-RU, respectively. Gallic acid, a major active component in JL-TH, may be responsible for this activity. The decreased lipid content in adipocytes due to the treatment of JL-TH and CD-H may be partially due to a decrease in cell numbers resulting from the inhibition of proliferation and the viability of adipocytes.

Caffeine was used as a positive control in this study. Our results showed that caffeine inhibited fat accumulation and reduced TG content in 3T3-L1 adipocytes. This was supported by the previous report that caffeine has anti-obesity effects on suppressing the intracellular lipid accumulation after complete differentiation of 3T3-L1 adipocytes in a dose-dependent manner [14]. Moreover, Kim et al. [15] reported that caffeine suppressed 3T3-L1 adipocyte differentiation and inhibited the expression of the CCAAT/enhancer binding protein (C/EBP) $\alpha$ and peroxisome proliferator-activated receptor (PPAR) $\gamma$ two main adipogenic transcription factors.

Fat accumulation is determined by the balance between fat synthesis (lipogenesis) and fat breakdown (lipolysis/fatty acid oxidation). Lipogenesis encompasses the processes of fatty acid synthesis and subsequent triglyceride synthesis and takes place in the liver and adipose tissues, while adipogenesis refers to the differentiation of preadipocytes into mature fat cells [16]. Inhibition 
of adipocyte differentiation presents a key strategy to control obesity since an increase in adipose mass is caused by both adipocyte hypertrophy and adipocyte hyperplasia [17]. In the present study, it had been found that M. citrifolia and herbs for weight loss (JL-TH, JL-RU, and CD-H) had anti-obesity activity related to adipogenesis in 3T3-L1 adipocytes.

However, the effects of these test samples on lipolysis and adipogenesis as well as the mechanism underlying these effects, such as the expression of key adipogenic transcription factors including peroxisome proliferator-activated receptor gamma $(\operatorname{PPAR} \gamma)$ and CCAAT/enhancer binding protein (C/EBP $\alpha$ ) [18], need to be explored.

Further evaluation of toxicity and via in vivo experiments need to be undertaken to support the therapeutic use of M. citrifolia leaf extract and the three herbal formulas as anti-obesity nutritional supplements. Combining several phytochemicals as herbal formulas or using them as lead compounds for the synthesis of new drugs has huge potential for targeting obesity prevention or as a treatment.

Modest increases in energy expenditure, inhibition of the absorption of carbohydrate or fat and inhibition of the proliferation and differentiation of preadipocytes have been postulated to account for the mechanisms of anti-obesity [19]. The inhibition of dietary triglyceride absorption via the inhibition of pancreatic lipase, which is the major source of excess calories, is another approach for the treatment of obesity [20]. Many pancreatic lipase inhibitors are reported from the plant sources. They show the antiobesity effects in the animal models, however, there is no plant inhibitor in the clinical use [21]. Moreover, there have been many previous reports which have explored novel substances derived from natural sources on adipogenic differentiation and gene regulation associated with obesity [22]. (a)

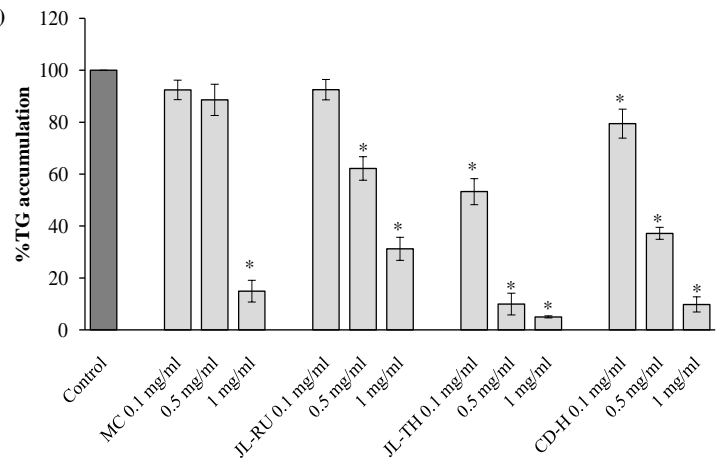

(b) 120

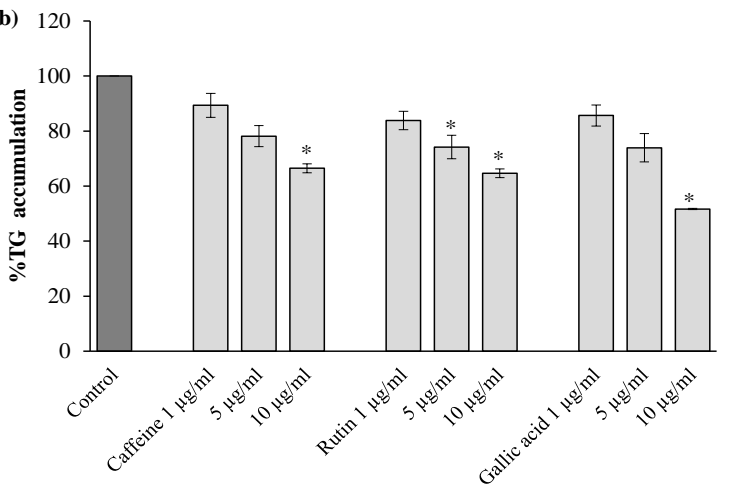

Fig. 4: Effects of (a) MC (M. citrifolia), herbal formulas (JL-RU, JLTH and CD-H), and (b) caffeine, rutin and gallic acid on triglyceride (TG) accumulation in 3T3-L1 adipocytes, compared to the control. Values are expressed as mean $\pm S E(n=3),{ }^{*} p<0.05$

Table 2: Inhibitory activity of MC (M. citrifolia), herbal formulas (JL-RU, JL-TH and CD-H), caffeine, rutin and gallic acid on lipid and triglyceride accumulation in 3T3-L1 adipocytes

\begin{tabular}{|c|c|c|c|}
\hline \multirow[t]{2}{*}{ Test samples } & \multirow[t]{2}{*}{ Concentration } & \multicolumn{2}{|l|}{ \%Inhibition } \\
\hline & & Lipid accumulation (Oil Red 0 staining) & Triglyceride accumulation \\
\hline \multirow[t]{3}{*}{ MC } & $0.1 \mathrm{mg} / \mathrm{ml}$ & $14.43 \pm 0.94 *$ & $7.55 \pm 3.78$ \\
\hline & $0.5 \mathrm{mg} / \mathrm{ml}$ & $26.91 \pm 1.56^{*}$ & $11.42 \pm 6.02^{*}$ \\
\hline & $1.0 \mathrm{mg} / \mathrm{ml}$ & $45.12 \pm 2.00^{*}$ & $85.09 \pm 6.02^{*}$ \\
\hline \multirow[t]{3}{*}{ JL-RU } & $0.1 \mathrm{mg} / \mathrm{ml}$ & $14.04 \pm 0.66^{*}$ & $7.44 \pm 3.92$ \\
\hline & $0.5 \mathrm{mg} / \mathrm{ml}$ & $44.22 \pm 0.76^{*}$ & $37.83 \pm 4.53^{*}$ \\
\hline & $1.0 \mathrm{mg} / \mathrm{ml}$ & $56.51 \pm 2.72 *$ & $68.76 \pm 4.43^{*}$ \\
\hline \multirow[t]{3}{*}{ JL-TH } & $0.1 \mathrm{mg} / \mathrm{ml}$ & $90.89 \pm 3.81^{*}$ & $46.76 \pm 5.00^{*}$ \\
\hline & $0.5 \mathrm{mg} / \mathrm{ml}$ & $107.01 \pm 0.69 *$ & $90.08 \pm 4.17^{*}$ \\
\hline & $1.0 \mathrm{mg} / \mathrm{ml}$ & $109.17 \pm 2.52^{*}$ & $95.00 \pm 0.39 *$ \\
\hline \multirow[t]{3}{*}{$\mathrm{CD}-\mathrm{H}$} & $0.1 \mathrm{mg} / \mathrm{ml}$ & $22.08 \pm 5.92$ & $20.59 \pm 5.57^{*}$ \\
\hline & $0.5 \mathrm{mg} / \mathrm{ml}$ & $47.18 \pm 5.89 *$ & $62.84 \pm 2.32^{*}$ \\
\hline & $1.0 \mathrm{mg} / \mathrm{ml}$ & $67.52 \pm 4.68^{*}$ & $90.20 \pm 2.89 *$ \\
\hline \multirow[t]{3}{*}{ Rutin } & $1 \mu \mathrm{g} / \mathrm{ml}$ & $29.01 \pm 4.31^{*}$ & $16.18 \pm 3.33$ \\
\hline & $5 \mu \mathrm{g} / \mathrm{ml}$ & $47.14 \pm 5.07^{*}$ & $25.80 \pm 4.25^{*}$ \\
\hline & $10 \mu \mathrm{g} / \mathrm{ml}$ & $57.80 \pm 8.41^{*}$ & $35.33 \pm 1.59^{*}$ \\
\hline \multirow[t]{3}{*}{ Gallic acid } & $1 \mu \mathrm{g} / \mathrm{ml}$ & $7.61 \pm 1.07^{*}$ & $14.35 \pm 3.84$ \\
\hline & $5 \mu \mathrm{g} / \mathrm{ml}$ & $27.48 \pm 2.25^{*}$ & $26.07 \pm 5.15$ \\
\hline & $10 \mu \mathrm{g} / \mathrm{ml}$ & $62.03 \pm 1.38^{*}$ & $48.33 \pm 0.22^{*}$ \\
\hline Caffeine & $1 \mu \mathrm{g} / \mathrm{ml}$ & $62.86 \pm 3.08^{*}$ & $10.65 \pm 4.34$ \\
\hline \multirow[t]{2}{*}{ (positive control) } & $5 \mu \mathrm{g} / \mathrm{ml}$ & $64.41 \pm 4.08^{*}$ & $21.84 \pm 3.82$ \\
\hline & $10 \mu \mathrm{g} / \mathrm{ml}$ & $68.69 \pm 8.15^{*}$ & $33.52 \pm 1.61^{*}$ \\
\hline
\end{tabular}

Values are expressed as mean \pm SE $(n=3)$, compared to the control; * $p<0.05$.

Phytochemicals are potential agents to inhibit the differentiation of preadipocytes, stimulate lipolysis and induce apoptosis of existing adipocytes, thereby reducing the amount of adipose tissue. Flavonoids and stilbenoids represent the most researched groups of phytochemicals with regards to their effect on adipogenesis. Phenolic acids, alkaloids and vitamins, as well as other plant compounds, were also studied both in vitro and in vivo. Many herbal formulations which have the potential on anti-obesity similar to our investigation were also reported. SH21B, which is an anti-obesity compound composed of seven herbs, inhibited fat accumulation in 3T3-L1 adipocytes and high fat diet-induced obese mice [23]. KBH-1, mixtures of Polygala tenuifolia, Curcuma longa and Saururus chinensis, inhibits lipid accumulation by down-regulating the major transcription factors of the adipogenesis pathway by regulating the 
AMPK pathway in 3T3-L1 adipocytes and in mice with HFD-induced obesity [24]. Although the mechanism of action of many traditional herbal medicines is still unknown, there are several instances of an herbal combination extract being more efficacious than an equivalent dose of one of its components alone [25]. Interestingly, phytochemicals isolated from herbs used in traditional medicine may only be effective in combination with other phytochemicals or components in the mixture by synergistic effects [26]. Therefore, developing an effective anti-obesity agent derived from natural products as herbal extract or formulation is a huge challenge to researchers and should be given more attention.

\section{CONCLUSION}

In conclusion, our results demonstrated that the M. citrifolia leaf extract and three herbal formulas efficiently inhibited adipogenesis in 3T3-L1 adipocytes in a dose-response relationship, as indicated by a significant reduction in intracellular lipid accumulation and triglyceride contents and cell viability. These findings suggested that M. citrifolia leaf extract and three herbal formulas for weight loss, especially JL-TH, might have a possible therapeutic approach for the prevention and treatment of obesity.

\section{CONFLICT OF INTERESTS}

We declare no conflict of interest in this research

\section{REFERENCES}

1. Glazer G. Long-term pharmacotherapy of obesity 2000: a review of efficacy and safety. Arch Intern Med 2001;161:1814-24.

2. Kopelman PG. Obesity as a medical problem. Nature 2000;404:635-41.

3. Leonhardt M, Hrupka B, Langhans W. New approaches in the pharmacological treatment of obesity. Eur J Nutr 1999;38:1-13.

4. Roh C, Jung U. Nepeta japonica maximowicz extract from natural products inhibits lipid accumulation. J Sci Food Agric 2012;92:2195-9.

5. Kang JG, Park C. Anti-obesity drugs: a review about their effects and safety. Diabetes Metab J 2012;36:13-25.

6. Bray GA, Tartaglia LA. Medicinal strategies in the treatment of obesity. Nature 2000;404:672-7.

7. Goswami P, Khale A, Shah S. Medicinal herbs and obesity: a review. Int J Pharm Sci Rev Res 2011;11:69-74.

8. Athesh K, Divakar M, Brindha P. Anti-obesity potential of Cyperus rotundus $\mathrm{L}$. aqueous tuber extract in rats fed on highfat cafeteria diet. Asian J Pharm Clin Res 2014;7:88-92.

9. Banjare J, Bhalerao S. A survey of marketed ayurvedic/herbal anti-obesity products. Int J Pharm Pharm Sci 2016;8:384-6.

10. Raja RR, Sreenivasulu M. Morinda citrifolia L.-Phytopharmacological perspective review. J Med Herbs Ethnomed 2015;1:68-74.

11. Saraphanchotiwitthaya A, Sripalakit P. Effect of Morinda citrifolia Linn. leaf extracts on in vitro lipase activity. Chiang Mai J Sci 2014;41:1182-93.
12. Mosmann T. Rapid colorimetric assay for cellular growth and survival: application to proliferation and cytotoxicity assays. J Immunol Methods 1983;65:55-63.

13. Wang YW, Jones PJH. Conjugated linoleic acid and obesity control: efficacy and mechanisms. Int J Obes 2004;28:941-55.

14. Nakabayashi H, Hashimoto T, Ashida H, Nishiumi S, Kanazawa K. Inhibitory effects of caffeine and its metabolites on intracellular lipid accumulation in murine 3T3-L1 adipocytes. Biofactors 2008;34:293-302.

15. Kim AR, Yoon BK, Park H, Seok JW, Choi H, Yu JH, et al. Caffeine inhibits adipogenesis through modulation of mitotic clonal expansion and the AKT/GSK3 pathway in 3T3-L1 adipocytes. BMB Rep 2016;49:111-5.

16. Kersten S. Mechanisms of nutritional and hormonal regulation of lipogenesis. EMBO Rep 2001;2:282-6.

17. Caro JF, Dohm LG, Pories WJ, Sinha MK. Cellular alterations in liver, skeletal muscle, and adipose tissue responsible for insulin resistance in obesity and type II diabetes. Diabetes Metab Rev 1989;5:665-89.

18. Li KK, Liu CL, Shiu HT, Wong HL, Siu WS, Zhang C, et al. Cocoa tea (Camellia ptilophylla) water extract inhibits adipocyte differentiation in mouse 3T3-L1 preadipocytes. Sci Rep 2016;6:20172.

19. Zhu HJ, Wang LJ, Wang XQ, Pan H, Li NS, Yang HB, et al. Hormone-sensitive lipase is involved in the action of hydroxy safflor yellow A (HYSA) inhibiting adipogenesis of 3T3-L1cells. Fitoterapia 2014;93:182-8.

20. Birari RB, Bhutani KK. Pancreatic lipase inhibitors from natural sources: Unexplored potential. for Drug Discov2007;12:879-89.

21. Singh G, Suresh S, Bayineni VK, Kadeppagari RK. Lipase inhibitors from plants and their medical applications. Int J Pharm Pharm Sci 2015;7:1-5.

22. Yang Y, Yang X, Xu B, Zeng G, Tan J, He X, et al. Chemical constituents of Morus alba L. and their inhibitory effect on 3T3L1 preadipocyte proliferation and differentiation. Fitoterapia 2014;98:222-7.

23. Lee H, Kang R, Yoon Y. SH21B, an anti-obesity herbal composition, inhibits fat accumulation in 3T3-L1 adipocytes and high fat diet-induced obese mice through the modulation of the adipogenesis pathway. J Ethnopharmacol 2010;17:709-17.

24. Lee J, Kim T, Lee J, Lee KJ, Kim H, Yun B, et al. The herbal medicine KBH-1 inhibits fat accumulation in 3T3-L1 adipocytes and reduces high-fat diet-induced obesity through regulation of the AMPK pathway. PLoS One 2015;10:e0142041.

25. Williamson EM. Synergy and other interactions in phytomedicines. Phytomedicine 2001;8:401-9.

26. Andersen C, Rayalam S, Della-Fera MA, Baile CA. Phytochemicals and adipogenesis. Biofactors 2010;36:415-22.

\section{How to cite this article}

- Aurasorn Saraphanchotiwitthaya, Pattana Sripalakit. Inhibition of lipid accumulation in 3T3-L1 adipocytes by Morinda citrifolia linn. leaf extracts and commercial herbal formulas for weight control. Int J Pharm Pharm Sci 2016;8(12):199-204. 